\title{
Strategies for Efficient Funding of Universities in Europe
}

\author{
Enora Bennetot Pruvot, Anna-Lena Claeys-Kulik \\ and Thomas Estermann
}

\section{Methodology}

The DEFINE project (2012-2015) is run by EUA in collaboration with CIPES, the Centre for Research in Higher Education Policies (PT), and the Universities of Oxford (UK), Aalto (FI) and Erlangen-Nuremberg (DE), and the Copenhagen Business School (DK). It is co-funded by the European Union under the Lifelong Learning Programme.

Research has been conducted within the framework of the DEFINE project in three phases. ${ }^{1}$ The data collection was first organised at system level through various rounds of consultations, questionnaires and interviews with National Rectors' Conferences, seeking to establish a detailed understanding of public funding mechanisms and their development over the past decade, identify frequent issues, and build a list of case studies for mergers and concentration measures. At this stage also a fourth pillar on operational efficiency measures at institutional level was integrated into the project structure as it appeared to be an important issue in several systems. This system level data, together with updated data of EUA's Public

\footnotetext{
${ }^{1}$ The study also explores the funding and management implications of mergers and concentration processes among higher education institutions. This paper does not include this pillar of the analysis, which is detailed in a thematic report available on http://www.eua.be/define.aspx.
}

E.B. Pruvot $(\square) \cdot$ A.-L. Claeys-Kulik · T. Estermann

European University Association, Brussels, Belgium

e-mail: enora.pruvot@eua.be

A.-L. Claeys-Kulik

e-mail: anna.lena.kulik@eua.be

T. Estermann

e-mail: thomas.estermann@eua.be

(C) The Author(s) 2015

A. Curaj et al. (eds.), The European Higher Education Area,

DOI 10.1007/978-3-319-20877-0_11 
Funding Observatory, ${ }^{2}$ enabled the project team to develop funding profiles of 24 European university systems. ${ }^{3}$

In addition, qualitative information focusing on the institutional level was obtained through self-evaluation exercises and site visits of three higher education institutions selected for their experience with the topics and mechanisms under scrutiny, ${ }^{4}$ as well as a seminar with university managers from across Europe organised in cooperation with HUMANE (Heads of University Management and Administration Network in Europe).

All of the above paved the way for three thematic focus groups. These groups gathered university leaders and managers with significant experience in the topic addressed (performance-based funding; merger and concentration processes; funding for excellence). The focus group format aimed to elicit feedback from practitioners on the impact and unintended consequences of the mechanisms analysed, and provide suggestions for improvement.

The analysis was presented to the wider university community on the occasion of the European University Association's Second Funding Forum in Bergamo, Italy in October 2014, which was used for validation and additional collection of case studies. Afterwards thematic reports and a final summary publication were released in 2015 .

\section{Funding of Higher Education Institutions}

The European University Association's work on the financial sustainability of universities has previously focused on the opportunities and challenges associated to the attraction of diverse income sources (Thomas and Pruvot 2011) and the development of adequate financial management tools such as full costing (Thomas et al. 2008, 2013). EUA has also set up a Public Funding Observatory to monitor the development of trends in public funding for universities throughout Europe on an annual basis since 2008 .

This paper primarily addresses evolutions in the ways public funding is delivered to universities, and how public authorities seek to calibrate these modalities to improve funding efficiency in the system. Early observations show that, while some funding tools are widely used in the countries considered in the analysis, they tend

\footnotetext{
${ }^{2}$ The annual reports since 2008 and the online tool are available here: http://www.eua.be/ publicfundingobservatory.be.

${ }^{3}$ Austria, Belgium-Flanders, Belgium-French speaking community, Switzerland Czech Republic, Germany-Brandenburg, Germany-Hesse, Germany-North-Rhine Westphalia, Denmark, Estonia, Spain-Catalonia, France, Hungary, Ireland, Iceland, Italy, Lithuania, Latvia, Netherlands, Norway, Poland, Portugal, Sweden, United Kingdom-England.

${ }^{4}$ Copenhagen Business School on the Danish taximeter system; Aalto University on the merger process and the University Erlangen-Nuremberg on the German Excellence Initiative.
} 
to cover different realities, thus making comparisons challenging. To understand these different realities one first needs to look at the overall funding context in each system.

\subsection{Income Structures}

Where system averages are available, public funding represents between 50 and $90 \%$ of the universities' income structures. There have often been significant changes in the modalities through which public funding is delivered. In addition, one should bear in mind the important cuts made in the budgets for universities in a number of countries since 2008, which are described in EUA's Public Funding Observatory. In 2014, 15 systems had lower public funding available to higher education institutions than in 2008 (taking inflation into account). ${ }^{5}$ Given the importance of this funding source for universities, changes in both the nature and overall amount potentially have the greatest effect on universities' long-term financial sustainability.

In 2013 tuition and administrative fees represented typically around $5 \%$ or less of the universities' income in the Nordic countries (Denmark, Finland, Iceland, Norway, Sweden), as well as in Austria, Belgium (both systems), the Czech Republic, Estonia, France and Germany. ${ }^{6}$

In nine countries tuition fees represented $10 \%$ or more of the universities' average income, and, as such, constitute the most important income source after public funding. Those include Hungary, Ireland, Italy, the Netherlands, Latvia, Poland, Slovakia and Spain, as well as the United Kingdom. However, as public authorities in many cases can decide about the introduction, abolishment or level of tuition fees, this income source can fluctuate considerably.

Generating additional income from other sources is therefore perceived as more and more necessary for the long-term financial sustainability of universities, and expectations of public authorities around this are rising. Here, we consider income generated by research contracts and provision of services (such as renting of facilities, catering services, consultancy, etc.), philanthropic funding, and, when possible, European funding. ${ }^{7}$ Overall, these types of additional income sources exceed $10 \%$ of the average universities' income in most systems (Thomas and Pruvot 2011, p. 27). A worrying trend though is that in some countries, national authorities tend to perceive European funds as a mechanism to compensate decreases in national public funding for the sector. This is problematic, not only because of the significant

\footnotetext{
${ }^{5} \mathrm{http}: / /$ www.eua.be/publicfundingobservatory.

${ }^{6}$ Estonia and Germany have recently abolished tuition fees for students completing their studies within the regular timeframe/obtaining a certain number of ECTS per year.

${ }^{7}$ It should be noted that European funds are not always identifiable in the universities' income structure; this may be for instance the case of structural funds, which are delivered by the national or regional authorities, and may be thus labelled as national/regional funds.
} 
amount of co-funding required, but also because European funds are allocated on a competitive basis - success in the competition requires institutional capacities and resources that in turn depend on financial means.

\subsection{Public Funding Modalities}

In most systems public authorities distribute funding to universities through block grants (see Fig. 1). The overall amount of the block grant may be determined in different ways though, through negotiation, on a historical basis, via a funding formula or through a performance contract. Often these elements are combined, meaning a part of the block grant is negotiated, another part might be determined on a historical basis, and again another part via a funding formula or a contract. The importance of these different elements in determining the overall amount of the block grant varies across the systems.

Public funding is also increasingly distributed based on competition, often through calls for project proposals, notably for research. Finally, other direct funding mechanisms also exist, such as targeted/earmarked funding for specific purposes, which may be allocated on a competitive basis, such as the Strategic Innovation Funding in Ireland, established as a mechanism for institutional restructuring and modernisation. Such funding may also be allocated directly to institutions (non-competitive): this is the case for the Higher Education Innovation Funding scheme in the United Kingdom, which focuses on knowledge exchange, or the "Successful Bachelor degrees" plan in France, which funds concrete measures aiming at improving the overall success rate in Bachelor degrees (e.g. individual supervision, new teaching methods).

Although formula-based block grants are the main way of delivering public funding in almost two thirds of the systems considered, negotiated block grants remain the most important mechanism in some big systems like France and Italy

Fig. 1 Public funding allocation mechanisms

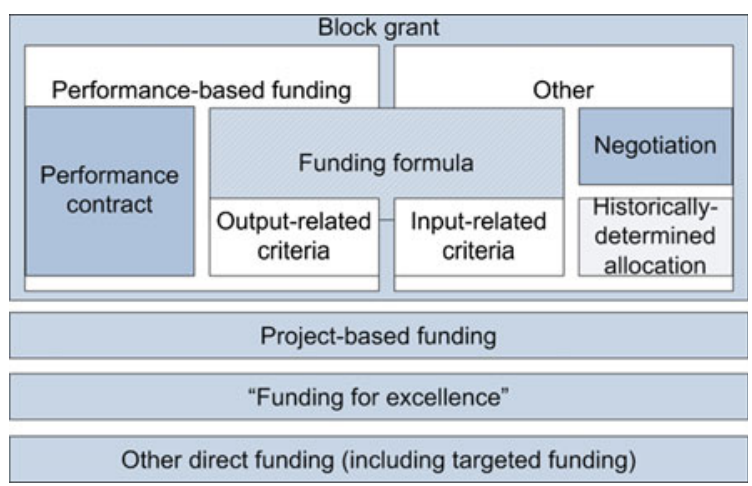


Table 1 An overview of allocation mechanisms for block grants across Europe

\begin{tabular}{|c|c|c|c|}
\hline & Funding formula & $\begin{array}{l}\text { Performance contracts } \\
\text { (with impact on } \\
\text { university funding) }\end{array}$ & $\begin{array}{l}\text { Negotiated or } \\
\text { historically-determined } \\
\text { block grant }\end{array}$ \\
\hline $\begin{array}{l}\text { Primary } \\
\text { mechanism }\end{array}$ & $\begin{array}{l}\text { Brandenburg (Germany), } \\
\text { Catalonia (Spain), Czech } \\
\text { Republic, Denmark }{ }^{\mathrm{a}} \text {, } \\
\text { England (UK), Finland, } \\
\text { Flanders and } \\
\text { French-speaking } \\
\text { Community of Belgium, } \\
\text { Hesse (Germany), } \\
\text { Hungary, Ireland, Iceland, } \\
\text { Latvia, Netherlands, }_{\text {Poland, Portugal, }} \\
\text { Romania }^{\mathrm{a}}, \text { Sweden }^{\mathrm{a}}\end{array}$ & Austria & $\begin{array}{l}\text { Denmark }^{\mathrm{b}}, \text { Estonia, } \\
\text { France, Italy, North } \\
\text { Rhine-Westphalia } \\
\text { (Germany), Norway, } \\
\text { Switzerland }\end{array}$ \\
\hline $\begin{array}{l}\text { Secondary } \\
\text { mechanism }\end{array}$ & $\begin{array}{l}\text { Estonia, France, Italy, } \\
\text { North Rhine-Westphalia } \\
\text { (Germany), Norway, } \\
\text { Sweden }^{\text {b }}\end{array}$ & $\begin{array}{l}\text { Brandenburg } \\
\text { (Germany), England } \\
\text { (UK), France, Hesse } \\
\text { (Germany), Ireland, } \\
\text { Latvia, Netherlands, } \\
\text { Portugal }\end{array}$ & $\begin{array}{l}\text { Austria, Catalonia, } \\
\text { Czech Republic, Hesse } \\
\text { (Germany), Hungary, } \\
\text { Poland, Sweden }\end{array}$ \\
\hline
\end{tabular}

Note that this table was compiled in autumn 2014, as the data validation phase of the DEFINE project was still ongoing. Therefore this classification is provisional and might look different in later publications

${ }^{\mathrm{a}}$ Teaching funding only

${ }^{\mathrm{b}}$ Research funding only

and a few smaller ones (see Table 1). Most countries however, have a mix of different allocation modalities, and a first analysis shows a great diversity between systems. The following table gives an overview of allocation mechanisms for block grants across the systems considered and is a first attempt to group them.

\section{Performance-Based Funding}

The term performance-based funding is being used more and more often in discussions on university funding policy at national, as well European levels. However, it is understood very differently across Europe. In many cases it is used as a synonym for formula-based funding, often without taking into account the "input" or "output" related nature of the criteria used in the formula. Often, performance-based funding is also perceived as competitive funding due to the fact that it is used to distribute a fixed amount of money to institutions based on their relative performance. Performance or development contracts, and target agreements whereby certain goals are agreed between the funder and universities are also associated with performance-based funding, although they do not always have a direct impact on funding and are of different nature. 


\subsection{Funding Formulae}

In many systems with formula funding, input indicators such as student numbers (at Bachelor level, then at Master level) often play the most important role in determining the amount of funding a university gets via a block grant. The corresponding output-oriented indicators (number of Bachelor and Master degrees) are used less frequently and or have often less weight in a formula. It is interesting to note the importance of some output-oriented criteria, which are usually linked to research output: doctoral degrees, international/European funding and external funding are considered the most important criteria, followed by teaching-related output criteria of Master and Bachelor degrees and ECTS points. Other commonly used output indicators are research evaluations and research contracts.

Current important policy priorities like internationalisation and student and staff mobility are also mirrored in funding formulae in several systems, through indicators such as the number of international students and albeit to a lesser extent the number of international staff. Denmark, for instance, uses an "internationalisation taximeter", granting the Danish universities a fixed amount per outgoing and incoming student. Finland takes account of the universities' international teaching and research personnel in its funding model, and all internationalisation-related criteria (including competitive international research funding) count for $9 \%$ of the public funding.

The set of indicators is crucial, as the interplay of different indicators determines the effects the formula might have on universities. Negative effects on the quality of teaching and research are debated with regard to several indicators. Here are just a few examples:

Formulae heavily relying on study completion bear the risk of a decrease in quality and standards to foster quicker completion. This may lead to bigger classrooms, as universities try to take-in as many students as possible without increasing the number of teaching staff or courses. This risk might be mitigated, for instance, through the combination of study completion criteria with more input-oriented indicators such as student and staff numbers, as well as the implementation of internal quality assurance mechanisms and the development of quality culture within the institution.

Bibliometric criteria tend to privilege natural and social sciences over humanities, as they more heavily rely on empirical research which translates into a higher number of publications. Furthermore, bibliometric criteria bear the risk of a decrease in quality if used too excessively, as they then foster slicing of papers and name dropping in publications. Therefore, bibliometric criteria should not be the only measure to allocate research funding. Discipline specific criteria need to be added to compensate for the potential risks.

External funding, which may be acquired through research contracts with private partners, EU funds, or other types of competitive funding or philanthropic sources, appears quite frequently as indicator in funding formula, which, in turn, sets the value of the core funding that the university receives. Creating a direct link between 
external funding and core funding may be used as an incentive for universities to actively develop partnerships, and strengthen income diversification strategies. However, if this incentive is used, it needs to take account of the fact that external funding often only offers partial coverage of costs. Universities then need to bridge the gap with their core resources. For it to be a sustainable mechanism, an increase in external funding obtained by the university needs to be coupled with a growth of the formula-based block grant, to cover the co-funding required by European and international funding programmes, as well as the indirect costs research and projects funded by those, as they are usually not fully covered. Reduced core resources will create additional barriers for universities to successfully obtain external funding because of a lesser capacity to bridge the associated funding gap (see Thomas et al. 2013, p. 12).

Also, indicators that are difficult to influence by universities should be used with caution. This is especially the case when criteria related to graduate employability are used (for example in Finland or Italy), and the quality of the teaching provided at the institution is only one of the determining factors. The institutional influence on student numbers may be limited by central regulation in some systems; legal provisions may also, for instance, hinder the capacity to attract international staff. More broadly, external factors such as the system-level regulatory frameworks, the general economic context, and the local environment or community in which the university develops its activities may have a stronger influence on the university's score for some criteria than the university itself, which undermines the assumed neutrality of a formula.

\subsection{Performance Contracts}

Another way of steering institutional behaviour is through so-called performance contracts, target agreements or development contracts, whereby certain goals are agreed between public authorities and universities. These are a common feature found in 15 of the systems considered in the study. However, they are of very different nature, and only in a few cases they do have a direct and clear impact on funding. Here are a few examples to illustrate the differences:

In Austria for instance, the contract is the outcome of a budget negotiation between the ministry and each university to determine the amount of funding per institution, whereby the minimum level is prefixed by law. The achievement of the contract's objectives can have an impact on the negotiations for the next funding period.

In the Netherlands, performance contracts were introduced in 2012 and since then a set amount of the block grant (currently $7 \%$ ) is distributed on the basis of objectives agreed between the Ministry of Education and individual universities in these contracts. After three years, a review commission will assess whether these objectives have been met, however it is to be seen whether this will then really have a direct impact on funding. 
In Brandenburg and Hesse, two of the three German Länder included in the study, a certain percentage ( $2 \%$ and respectively $5 \%$ ) of the block grant is linked to the achievement of the objectives agreed upon in the performance contracts specific to each university. However, the assessment is not very rigorous and underperformance is rarely sanctioned by funding cuts.

In Denmark, the development contracts are on purpose not linked to funding, but they are nevertheless seen as an important steering mechanism also by university management, as they can be used in discussions on the institutional strategy and internal funding allocation. Here, the impact on institutional management very much depends on the structure and the governance model of the institution.

A performance contract may also be used as a complementary instrument to a funding formula either to align the contract's objectives with the formula, or to mitigate some of the negative effects of a formula by, for instance, setting additional objectives for the quality of teaching and research. If it is an individual contract, this is also the opportunity to create a dialogue between the ministry and the university, and it can then be used as an effective management tool even if it is not directly linked to funding.

\subsection{Overview of Performance Elements in Block Grant Allocation}

A majority of systems consider their funding allocation mechanisms at least partially performance-based for teaching (via graduate-related criteria), with the most extensive case being Denmark (through its taximeter system to allocate funds for teaching), and partially or mainly performance-based for research, where indicators related to publications and external research funding are normally taken into account.

Table 2 shows that a primarily input-based formula is the most common way of block grant allocation for the systems considered in the study. However, it is often combined with other mechanisms, such as performance contracts or budget negotiations and historical allocation.

\subsection{Effects of Performance-Based Funding on Higher Education Systems}

Each parameter used in the funding system, whether it is an indicator within the funding formula or an objective in a performance contract, comes with potential risks and unintended effects. However, there are several ways of mitigating these risks, either within the formula, through a careful combination of different funding mechanisms, or through other measures, such as quality assurance to counterbalance 
Table 2 An overview of allocation mechanisms for block grants across Europe, differentiating among formula types

\begin{tabular}{|c|c|c|c|c|}
\hline & \multicolumn{2}{|l|}{ Funding formula } & \multirow{2}{*}{$\begin{array}{l}\text { Performance } \\
\text { contracts (with } \\
\text { impact on } \\
\text { university } \\
\text { funding) }\end{array}$} & \multirow{2}{*}{$\begin{array}{l}\text { Negotiated or } \\
\text { historically-determined } \\
\text { block grant }\end{array}$} \\
\hline & $\begin{array}{l}\text { Primarily } \\
\text { input-oriented }\end{array}$ & $\begin{array}{l}\text { Primarily } \\
\text { output-oriented }\end{array}$ & & \\
\hline $\begin{array}{l}\text { Primary } \\
\text { mechanism }\end{array}$ & $\begin{array}{l}\text { Brandenburg } \\
\text { (Germany), } \\
\text { Catalonia } \\
\text { (Spain), Czech } \\
\text { Republic, } \\
\text { French-speaking } \\
\text { Community of } \\
\text { Belgium, Hesse } \\
\text { (Germany), } \\
\text { Hungary, } \\
\text { Ireland }{ }^{\mathrm{a}} \text {, Iceland, } \\
\text { Latvia, }_{\text {Netherlands, }} \\
\text { Poland } \\
\text { Portugal, } \\
\text { Romania }^{\mathrm{a}} \text {, } \\
\text { Sweden }^{\mathrm{a}}\end{array}$ & $\begin{array}{l}\text { Denmark }^{\mathrm{a}}, \\
\text { England (UK), } \\
\text { Finland, } \\
\text { Flanders } \\
\text { (Belgium), } \\
\text { Ireland } \\
\text { Poland }\end{array}$ & Austria & $\begin{array}{l}\text { Denmark }^{\mathrm{b}}, \text { Estonia, } \\
\text { France, Italy, North } \\
\text { Rhine-Westphalia, } \\
\text { Norway, Switzerland }\end{array}$ \\
\hline $\begin{array}{l}\text { Secondary } \\
\text { mechanism }\end{array}$ & & $\begin{array}{l}\text { Estonia, } \\
\text { France, Italy, } \\
\text { North Rhine- } \\
\text { Westphalia } \\
\text { (Germany), } \\
\text { Norway, } \\
\text { Sweden }\end{array}$ & $\begin{array}{l}\text { Brandenburg } \\
\text { (Germany), } \\
\text { England (UK), } \\
\text { France, Hesse } \\
\text { (Germany), } \\
\text { Ireland, Latvia, } \\
\text { Netherlands, } \\
\text { Portugal }\end{array}$ & $\begin{array}{l}\text { Austria, Catalonia, } \\
\text { Czech Republic, Hesse } \\
\text { (Germany), Hungary, } \\
\text { Poland, Sweden }\end{array}$ \\
\hline
\end{tabular}

Please note that when this table was made in autumn 2014, the data validation phase of the DEFINE project was still ongoing. Therefore this classification is provisional and might look different in later publications

${ }^{a}$ Teaching funding only

${ }^{\mathrm{b}}$ Research funding only

the negative effects. Within a funding formula, some negative effects of one indicator might be counterbalanced, for instance, by reducing the weight of this indicator with regard to other criteria used to determine the amount of funding. The choice of indicators and objectives is crucial and should be motivated by a clear policy, taking into account the diversity of institutional profiles. A formula or performance contract heavily relying on one or a very small number of indicators/objectives has a stronger steering effect, but this might also lead to a convergence of institutional profiles adapting their activities accordingly, and might thus contribute to reduce institutional diversity if most of the recurrent funding is allocated this way. A formula or performance contract with more indicators or objectives addressing different university activities might be more adequate to properly fund the broad mission of 
comprehensive universities (see also Dohmen 2014, p. 26). The articulation with other funding instruments and modes of funding is extremely important, as it determines the funding environment and thus the effects on institutional behaviour.

\section{Funding for Excellence}

In many European countries, intense pressure is exerted on the higher education system to adapt to evolving economic and societal demands, as well as to the "culture of excellence" necessary to operate in an increasingly internationally competitive field. Policy responses to these challenges take many forms. Some countries have made extra financial resources available to foster the emergence of excellence "hubs" with a view to enable these entities (whether institutions, clusters of institutions, or clusters of sub-institutional entities) to compete internationally, to improve research and/or teaching quality, as well as to match better supply and demand on the higher education market. However, in a context of constrained resources, excellence schemes are also meant to increase funding efficiency, whether as a main objective or not. They often aim to remove inefficiencies and to concentrate funding by creating hierarchies between institutions.

\subsection{Characteristics of Excellence Schemes in Higher Education}

While it is common for the notion of "excellence" to be integrated in research funding, notably through competitive funding mechanisms, it is less often attached to broad restructuring processes.

Excellence schemes differ from regular competitive funding because they are essentially characterised as "exceptional", meaning that they are introduced as a separate measure outside of the existing regular funding mechanisms, and are also often meant to be limited in time, with, in case of perceived success, the possibility to renew the experience.

Their scope and intended recipients are also broader than in the case of regular competitive funding, targeting the institutional level, more often than not involving arbitration and commitment by the institutional leadership.

In this regard, Germany's "Exzellenzinitiative" offers a benchmark against which other schemes can be compared. The French "Investment for the Future" scheme is partly modelled on the German example. Both initiatives are supported by large funds, albeit distributed through different mechanisms. These schemes are multi-fold and reward not only research clusters, but also institutional strategies; in Germany the scheme also funds the establishment of doctoral schools. The Spanish programme "Campus of International Excellence" also addresses different objectives, 
Table 3 A selection of "excellence schemes" found in Europe

\begin{tabular}{l|l}
\hline System & Scheme \\
\hline Austria & Creation of Institute of Science and Technology \\
\hline France & Excellence Initiatives (IDEX) \\
\hline Finland & Centres of Excellence in Research Creation of Aalto University \\
\hline Germany & Excellence Initiative \\
\hline Norway & "Centres of Excellent Research" \\
\hline Poland & "Leading National Research Centres" (KNOWs) \\
\hline Spain & "Campus of International Excellence" Programme (CEI) \\
\hline United Kingdom & "Research Excellence Framework" \\
\hline
\end{tabular}

among which regional integration of universities features prominently, and is built on a combination of funding mechanisms. Elsewhere, schemes are significantly smaller and typically address sub-institutional entities, such as laboratories, and usually require them to cluster or establish research consortia, as the Polish "Leading National Research Centres" or the Norwegian "Centres of Excellent Research". The creation of new excellent institutions like in Austria or Finland is considered here as well as a form of excellence funding, in particular given the concentration of resources and the narrative surrounding these processes; finally, it may be embedded in regular core funding, such as the Research Excellence Framework in the UK.

It is also worth noting that excellence in teaching is an objective addressed less often than excellence in research, where the perception of international competition is perhaps more acute. Nevertheless, some systems have set up schemes focusing on teaching excellence. This is for instance the case of the French "IDEFI" scheme, which funds innovative teaching, or the "Quality Pact for Teaching" in Germany, which aims at improving the conditions of study and teaching quality.

Table 3 shows the measures included in the analysis.

\subsection{Impact on Institutional Profiling and Restructuring}

The more intense international competition for talent and for funds requires universities to make themselves more visible on the international stage, and distinguish themselves from competitors by developing a strategic profile. Excellence schemes are an instrument available to public authorities to promote this, with strategic profiling becoming a dimension of the application and granting process. Universities are therefore encouraged to identify, strengthen and capitalise on their strengths and assets.

Universities may invest strategically internally to create leverage effects. They may, for instance, provide seed funding to high-potential initiatives, creating an "internal excellence scheme" focused on the young generation. Such initiatives may thus be seen as a stepping stone towards success in the large-scale excellence scheme; they may also be envisaged as a corrective mechanism to perceived 
shortcomings of the excellence scheme, that tend to privilege established research teams over promising ones; disciplinary over interdisciplinary work; certain types of academic fields over others.

This drive towards "profiling" or, to some extent, towards specialisation inevitably creates tensions within universities which, as comprehensive institutions, have a tradition of maintaining academic portfolios. In a context where institutions have often struggled to keep an acceptable balance between disciplines and academic fields, the pressure to focus on a limited number of flagship disciplines or even niches requires a real, concerted effort and innovative decision-making in the university.

The institution may also seek to adapt its own structure to improve its capacity to meet the excellence scheme requirements in terms of governance and flexibility, as well as enhance its ability to profile itself strategically. It was observed in the context of the study that restructuring tends to privilege flatter structures, sometimes eliminating intermediary levels of management such as faculties, and also favours reduced numbers of sub-institutional entities (larger schools/faculties/departments).

\subsection{The Role of the University Leadership}

In this light, the university central leadership is a key actor in all processes, from bringing together the various communities of the institution to making strategic decisions linked to profiling. The university leadership takes decisions related to the strategic reallocation of resources, a particularly acute question since it results in privileging particular areas or groups within the university often at the expense of others. It is the role of the university leadership to ensure the long-term sustainability of the activities funded under the excellence scheme, which by definition offers temporary support, and therefore requires a carefully planned exit strategy. The leadership must work towards the acceptance of sometimes difficult changes associated with restructuring and reallocation of resources. It must foster the development of an institution-wide strategy while preserving the institutional balance.

\subsection{Exit Strategies for Institutions and Systems}

Crucially, excellence schemes are viewed as time-bound initiatives to drive change, rather than a permanent funding mechanism. While in some cases it is possible to apply for a second grant, the underlying concept is one of temporary support.

Exit strategies are an important dimension of the sustainability challenge. Funding received by institutions in the framework of an excellence scheme supports additional, high-profile activities that in turn create high expectations and trigger new equipment and personnel costs. 
Universities participating in large-scale excellence schemes may thus have to think strategically about the internal allocation of resources over the long term, notably to make resources available to cover the non-externally funded part of the activities, as for instance indirect costs. Excellence schemes may therefore have extensive consequences on the internal resource management of the universities.

By the time the funds run out, the institution must have fully implemented a leverage strategy helping to generate additional funds from private partners in order to maintain - if not further raise - the new higher level of activity. Candidate institutions often have to detail their sustainability plan at the stage of selection.

Public authorities and the university sector need to agree on an exit strategy for the excellence scheme itself. All stakeholders need to consider how successfully started initiatives may be maintained over the longer term with other types of funders supporting the activities undertaken. This question is particularly acute in countries where the financial situation has significantly deteriorated over the lifetime of the excellence scheme.

\section{Efficiency Measures}

Universities themselves contribute to shaping their environment, not only by adapting institutional behaviour to respond to the external pressures and incentive mechanisms set at system level, but also by actively seeking to improve their operations at institutional level. Discussions about operational efficiency at institutional level are taking place in a number of systems, albeit with different narratives and expectations towards universities. A more structured dialogue between public authorities and universities about efficiency has developed in the UK and Ireland, where universities themselves work as agenda-setters and proactively started communicating about the topic (see Universities UK 2013).

\subsection{Types of Efficiency Measures}

In many systems, such measures are imbedded in universities' day-to-day operations, but they are not explicitly referred to as efficiency measures. A good example for this is the use of information and communication technology and specific software in administrative processes, with a view to facilitate for instance enrolment or registration for courses.

When looking at existing practices across Europe, two types can be distinguished, administrative and academic measures, for which some examples are given in Table 4.

With regard to the academic practice, there is often a trade-off between efficiency and the quality of teaching, for instance when universities are pressed to ensure faster completion, which bears the risk of lowering standards to make students pass 
Table 4 Examples of administrative and academic measures fostering efficiency

\begin{tabular}{l|l}
\hline \multirow{2}{*}{$\begin{array}{l}\text { Administrative } \\
\text { measures }\end{array}$} & $\begin{array}{l}\text { Collaboration to drive costs down like joint procurement, asset sharing, } \\
\text { shared services }\end{array}$ \\
\cline { 2 - 2 } & Use of information and communication technology \\
\cline { 2 - 2 } Estates and facility management to reduce infrastructure costs \\
\cline { 2 - 2 } $\begin{array}{l}\text { Financial management and full costing to better understand and } \\
\text { strategically reduce costs }\end{array}$ \\
\cline { 2 - 2 } Improvement of administrative processes \\
\cline { 2 - 2 } measures & Human resource practices and regulations \\
\cline { 2 - 2 } Organisational restructuring \\
\hline & Control of student numbers \\
\cline { 2 - 2 } & Faster completion \\
\cline { 2 - 2 } & Rationalisation of curricula \\
\cline { 2 - 2 } & Changes to student/staff ratio \\
\cline { 2 - 2 } & Collaborations, such as joint programmes and research \\
\hline
\end{tabular}

exams similarly to what was described with regard to completion criteria in funding formula. Similar pressure on the efficient use of funds comes from research funders who develop stricter scrutiny of projects and research activities. Therefore, it is all the more important that universities are enabled to develop their own strategies trying to balance efficiency and effectiveness and keeping up high quality standards.

In the administrative and the academic spheres, collaborations are a widespread means helping to make more efficient use of resources. Collaboration is sometimes driven by external pressures or incentives. Situations vary in Europe; sector collaboration may be the initiative of the universities themselves, or the impulse may be given by the public authorities. Institutions work together to secure additional money from specific funding schemes or to obtain large research infrastructures. Sector-level procurement is also a mechanism used in certain countries. This type of collaboration raises specific challenges, however, in particular in relation to the capacity to agree on the specific terms of reference. In some countries, dedicated agencies are set up for that purpose exclusively, although institutions are not obliged to use their services. This is important as regards the possible tension between achieving economies of scale on the one hand, and preserving some flexibility in the system on the other hand. Collaborative contracting with external providers seems most widespread in the area of maintenance services (IT services, security, catering); it seems there is ground for further collaboration in other fields.

\subsection{Enabling Frameworks}

The capacity of universities to implement efficiency measures partly depends on the governance and management structure and the degree of (de)centralisation of the institution. Highly decentralised structures, where faculties benefit from significant 
autonomy from the central university management, face a bigger challenge in terms of cost efficiency, as the steering capacity of the central university management is limited. In such cases, there is however scope for action at the level of streamlining processes across sub-institutional units. There is also a case for sharing infrastructures, including IT services, as well as launching a common procurement process at the level of the institution. Centralised institutions have most of these elements dealt with by the central university management and can therefore save costs through economies of scale.

Regulatory frameworks strongly determine the capacity to develop and implement such strategies. In systems where universities do not benefit from significant autonomy, implementing efficiency measures may be more difficult, whether within the institution or through cooperation mechanisms. This is relevant for all dimensions of autonomy; organisational autonomy is necessary to create legal entities as appropriate, or adapt academic structures in ways to foster synergies and lead to efficiencies. Financial autonomy is a prerequisite for efficient estate management (enabling the university to own its buildings). Academic autonomy makes it possible to combine or create new programmes in a sustainable way. Finally, autonomy in staffing matters allows the university to decide on positions and salaries. It is also worth noting that political objectives for the sector may be conflicting; when the funding model seeks to foster competition among institutions, it may hinder opportunities to collaborate.

\section{Conclusions}

Public authorities have many steering levers at their disposal to shape their higher education systems, with a view to enhance efficiency. It should, however, be kept in mind that measures such as performance-based funding and excellence schemes can also have unintended consequences at system, as well as institutional level.

The analysis shows that funding instruments and efficiency measures should be considered within the overall funding system and the particular context in which universities operate. When designing new instruments or changing the modalities, the political goal behind this should be clearly communicated and a long-term perspective and a holistic view should be taken to consider also potential unintended effects. A continuous consultation with the sector is crucial to ensure that the schemes fit their purpose and the needs of the institutions. Administrative procedures should be kept as simple as possible; transparency of the funding instruments and clarity of rules to all actors are equally important. It should also be clear whether the mechanism is meant as a steering instrument to incentivise a certain institutional behaviour or whether it is a means to redistribute a set amount of money. If the intention is to promote a certain type of behaviour, it should be kept in mind that most of the costs of a university's activities are fixed. In a context of reduced public funding, there is therefore little room for manoeuvre in this respect. Setting up adequate steering mechanisms requires either an injection of additional 
funding in the system, or freeing up resources through cost control (for example by adapting the volume of teaching or research activities). But funding models, in turn, can help universities in developing their own strategies to deal with changes in funding, provided they have the necessary autonomy to do so. Additional funding for universities can also be used to incentivise efficiencies at institutional level through support for collaborations in varies areas to share services, resources or real estate. Universities themselves should proactively engage in the development of funding policies with policy makers to ensure that the schemes respond to their needs.

Notwithstanding the increased need to rationalise and focus on value for money, efficient public funding models also need to provide sufficient and sustainable core funding to universities for them to properly fulfil their mission and respond to new challenges and societal demands.

Further findings and outcomes of the DEFINE project, including detailed recommendations to policy makers and university leaders, are available via the project website: http://www.eua.be/define.

Open Access This chapter is distributed under the terms of the Creative Commons Attribution Noncommercial License, which permits any noncommercial use, distribution, and reproduction in any medium, provided the original author(s) and source are credited.

\section{References}

Dohmen, D. (2014). Performance-based funding in Germany's higher education system. Paper presented at the EUA Funding Forum, Bergamo, Italy. http://www.eua.be/Libraries/Funding Forum/Dohmen_EUA-Bergamo_Performance-based-Funding_141008.sflb.ashx

EUA Public funding observatory annual reports and online tool. (2008). Available at: http://www. eua.be/eua-work-and-policy-area/governance-autonomy-and-funding/public-fundingobservatory-tool.aspx

Thomas, E., Hanna, K., \& John H. S. (2008). Towards full costing in European universities. Retrieved from http://www.eua.be/Libraries/Publications_homepage_list/Financially_ Sustainable_Universities-1.sflb.ashx

Thomas, E., \& Pruvot, B. E. (2011). European universities diversifying income streams. Retrieved from http://www.eua.be/Libraries/Publications_homepage_list/Financially_Sustainable_ Universities_II_-_European_universities_diversifying_income_streams.sflb.ashx

Thomas, E., \& Claeys-Kulik, A. -L. (2013). Full costing: Progress and practice. Retrieved from http://www.eua.be/Libraries/Publications_homepage_list/Full_Costing_Progress_and_ Practice_web.sflb.ashx

Thomas, E., Pruvot, B. E., \& Claeys-Kulik, A. -L. (2013). Designing strategies for efficient funding of higher education in Europe. DEFINE interim report. Retrieved from http://www. eua.be/Libraries/Publication/DEFINE_final.sflb.ashx

Universities UK. (2013). Working for a smarter, stronger sector. Efficiencies and effectiveness in higher education - progress report. http://www.universitiesuk.ac.uk/highereducation/ Documents/2013/WorkingForAsmarterStrongerSector.pdf 